\title{
Photochemical efficiency, biomass and chlorophyll of phyális under salinity and biostimulant
}

\author{
Jackson Silva Nóbrega ${ }^{1 *} \oplus$, Reynaldo Teodoro de Fátima ${ }^{2} \bullet$, Jean Telvio Andrade Ferreira ${ }^{2}{ }^{\oplus}$,

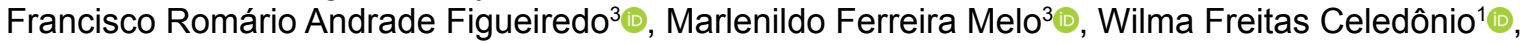 \\ Francisco Jean da Silva Paiva ${ }^{2} \oplus$, Thiago Jardelino Dias ${ }^{1}[0$

\footnotetext{
1 Universidade Federal da Paraíba, Centro de Ciências Agrárias, Areia, PB, Brasil. E-mail: jacksonnobrega@hotmail.com; wilmaceledonio@hotmail.com; thiagojardelinodias@gmail.com ${ }^{2}$ Universidade Federal de Campina Grande, Campina Grande, PB, Brasil. E-mail: reynaldo.t16@gmail.com; jeantelvioagronomo@gmail.com; je.an_93@hotmail.com
} \\ ${ }^{3}$ Universidade Federal Rural do Semi-Árido, Mossoró, RN, Brasil. E-mail: romarioagroecologia@yahoo.com.br; marlenildo@gmail.com
}

ABSTRACT: Physalis peruviana L. has great exploitation potential especially for small producers in the Brazilian Northeast. However, production in semiarid regions may be limited by high salt content in soils and water sources used for irrigation. Thus, this study evaluated the application of Ascophyllum nodosum seaweed extract as saline stress attenuator in P. peruviana L. The randomized block design was used, in an incomplete $5 \times 5$ factorial scheme, with five of electrical conductivities of the irrigation water $\left(0.50,1.23,3.00,4.77\right.$ and $\left.5.50 \mathrm{dS} \mathrm{m}^{-1}\right)$ and five increasing concentrations of kelp extract $(0.00,1.45,5.00,8.55$ and 10.00 $\mathrm{mL} \mathrm{L}^{-1}$ ), with nine combinations generated by the Central Box matrix, with four replicates of four plants to evaluate the effect on phytomass accumulation, chlorophyll fluorescence and pigment content. Results showed, salinity significantly reduced biomass production and chlorophyll fluorescence and pigment indices. However, when plants were treated with $9.9 \mathrm{~mL} \mathrm{~L}^{-1}$ seaweed extract they increased biomass production and seedling quality. On the other hand, up to $4.1 \mathrm{~mL} \mathrm{~L}^{-1}$, the biostimulant increased dark-adapted fluorescence indices which indicate it reduces damages to the photosynthetic apparatus caused by salt-stress and thus improving photosynthetic activity and photoassimilates production. Thus the application of $A$. nodosum seaweed extract attenuates the deleterious effect of salt stress in photosynthesis and thus in biomass production of $P$. peruviana plants.

Key words: Ascophyllum nodosum L.; Physalis peruviana L.; plant physiology; saline stress

\section{Eficiência fotoquímica, biomassa e clorofila}

\section{da phisális sob salinidade e biostimulante}

RESUMO: A Physalis peruviana L., apresenta grande potencial de exploração, especialmente para pequenos produtores do Nordeste Brasileiro. No entanto, a produção em regiões semiáridas pode ser limitada pelo alto teor de sais contidos no solo e nas fontes de água utilizadas na irrigação. Assim, este estudo avaliou a aplicação do extrato de algas marinhas Ascophyllum nodosum como atenuador de estresse salino em P. peruviana $\mathrm{L}$. O delineamento de blocos casualizados foi utilizado, em esquema fatorial incompleto $5 \times 5$, sendo cinco de condutividades elétricas da água de irrigação $(0,50,1,23$, $3,00,4,77$ e 5,50 dS m$\left.{ }^{-1}\right)$ e cinco concentrações crescentes do extrato de alga marinha $\left(0,00,1,45,5,00,8,55\right.$ e $\left.10,00 \mathrm{~mL} \mathrm{~L}^{-1}\right)$, com nove combinações geradas pela matriz Central de Box, com quatro repetições de quatro plantas para avaliar o efeito no acúmulo de fitomassa, fluorescência e teor de pigmentos da clorofila. Os resultados mostraram que a salinidade reduziu significativamente a produção de biomassa e os índices de fluorescência e pigmentos da clorofila. No entanto, quando as plantas foram tratadas com $9,9 \mathrm{~mL} \mathrm{~L}^{-1}$ de extrato de algas marinhas, elas aumentaram a produção de biomassa e a qualidade das mudas. Por outro lado, até 4,1 $\mathrm{mL} \mathrm{L}^{-1}$, o bioestimulante aumentou os índices de fluorescência adaptada ao escuro, 0 que indica que ele reduz os danos ao aparato fotossintético causados pelo estresse salino, melhorando assim a atividade fotossintética e a produção de fotoassimilados. Assim, a aplicação de extrato de alga marinha $A$. nodosum atenua o efeito deletério do estresse salino na fotossíntese e, consequentemente, na produção de biomassa de plantas de $P$. peruviana.

Palavras-chave: Ascophyllum nodosum L.; Physalis peruviana L.; fisiologia vegetal; estresse salino

\footnotetext{
* Jackson Silva Nóbrega - E-mail: jacksonnobrega@hotmail.com (Corresponding author)

Associate Editor: Maria do Céu Monteiro Cruz
} 


\section{Introduction}

Physalis peruviana L., known as camapú and fisális, has gained wide acceptance among farmers and consumers, due to their peculiar organoleptic traits of fruits, and high vitamins $A$ and $C$ content as well as medicinal substances (Fischer et al., 2014). However, $P$. peruviana exploitation in semiarid regions is severely affected by environmental and edaphoclimatic conditions.

Brazilian Northeast show low rainfall and suffers from water scarcity and high salt content in soils and water sources used for irrigation. Such conditions severely affect the development of crops in the region (Almeida et al., 2019). The high salt content in water and soil causes salt stress in plants which may disturb growth and development, by mainly affecting the photosynthetic apparatus (Cavalcante et al., 2019), resulting in biomass production losses.

To mitigate the deleterious effects of salt stress on plants, organic products have been used to stimulate the plant defence system. Among these products, biostimulants are able to act on plant transcription and thus activate secondary metabolism, alter phytohormones concentration and dynamics, improve the biological properties of plants, increase nutrient uptake and modify nutrition, and hence stimulate plant growth (Abdel-Raouf et al., 2012) under salt stress conditions (Jithesh et al., 2019).

Among the biostimulants used in agriculture, Ascophyllum nodosum (L.) Le Jolis seaweed-based extracts stood out for containing plant hormones that regulate and stimulate plant growth in addition to macro and micronutrients, pigments, vitamins, amino acids and others osmoprotective compounds (Michalak et al., 2016; Soares et al., 2018; Raghunandan et al., 2019). The attenuating effect of applying $A$. nodosum extract is reported for several crops, as in the case of Rosa et al. (2021) that improved the antioxidant activity of soybean (Glycine max L.) increasing productivity under water stress. Popescu (2020) attenuated the effect of salinity on the growth of cucumber (Cucumis sativus L.) and tomato (Solanum lycopersicum L.). AlMaliki et al. (2019) reduced the effect of water stress on the growth of onion (Allium cepa L.).

Thus, this work was carried out to evaluate the effect of Ascophyllum nodosum (L.) Le Jolis extract application on phytomass, fluorescence and photosynthetic pigments of $P$. peruviana L. under saline water irrigation.

\section{Materials and Methods}

The experiment was carried out in 2019 under greenhouse condition in the Department of Crop and Environmental Sciences from the Center of Agrarian Sciences, Federal University of Paraíba (UFPB), Areia city, Paraíba State, Brazil ( $6^{\circ} 57^{\prime} 42^{\prime \prime}$ S, 3541'43" W, 573 above the sea level). The climate, according to the Köppen classification, is As' type that is dry and hot summer with rain in winter, with $21.7^{\circ} \mathrm{C}$ average temperature and $1.305 \mathrm{~mm}$ a year rainfall. The experiment lasted 90 days, being conducted from August to October 2019.
The experimental design was in randomized blocks in an incomplete $5 \times 5$ factorial scheme with four replications and four plants per plot, where nine treatments were generated through the central composite design (CCD), with the minimum $(-\alpha)$ and maximum $(\alpha)$ values 0.5 and $5.5 \mathrm{dS} \mathrm{m}^{-1}$, respectively, for electrical conductivity of irrigation water (ECW) and 0.0 and $10 \mathrm{~mL} \mathrm{~L}^{-1}$ for seaweed-based biostimulant doses (BD) (Table 1). The use of CCD allows to evaluate the effect of two or more factors with a smaller number of treatments, optimizing space and work, preserving the efficiency and quality of the results, being the CCD widely used for factorial scheme of up to three factors and suitable for adjustment quadratic surface (Hang et al., 2011).

Seedlings were produced using seeds obtained from healthy and pest-free fruits produced in Pombal, Paraíba, Brazil. Seeds were sown in polystyrene bags of $1.2 \mathrm{dm}^{-3}$ capacity filled with a substrate composed of Latosol (Embrapa, 2018), cattle manure, and washed sand in a 3:1:1 ratio by volume. The substrate has the following chemical characteristics: $P=$ $85.55 \mathrm{mg} \mathrm{kg}^{-3} ; \mathrm{K}^{+}=693.60 \mathrm{mg} \mathrm{kg}^{-3} ; \mathrm{Na}^{+}=0.23 \mathrm{cmol}_{\mathrm{c}} \mathrm{dm}^{-3} ; \mathrm{H}^{+}$ $+\mathrm{Al}^{+3}=0.00 \mathrm{cmol}_{\mathrm{c}} \mathrm{dm}^{-3} ; \mathrm{Al}^{+3}=0.00 \mathrm{cmol}_{\mathrm{c}} \mathrm{dm}^{-3} ; \mathrm{Ca}^{+2}=2.91 \mathrm{cmol}_{\mathrm{c}}$ $\mathrm{dm}^{-3} ; \mathrm{Mg}^{+2}=1.59 \mathrm{cmol}_{\mathrm{c}} \mathrm{dm}^{-3} ; \mathrm{pH}=7.8 ; \mathrm{BS}=6.50 \mathrm{cmol}_{\mathrm{c}} \mathrm{dm}^{-3}$; $\mathrm{CEC}=6.50$; O.M. $=22.21 \mathrm{~g} \mathrm{~kg}^{-1}$.

The saline waters with different electrical conductivities were prepared by adding sodium chloride $(\mathrm{NaCl})$ to the potable water from the UFPB supply system that had 0.5 $\mathrm{dS} \mathrm{m}^{-1} \mathrm{EC}$. The desired ECw was obtained by the Equation 1 proposed by Lima et al. (2001).

$$
\mathrm{CS}=0.01\left(\frac{\mathrm{ECw}-0.4}{\mathrm{Pd}}\right) \times \mathrm{Weq}
$$

where CS is the ionic concentration $\left(\mathrm{g} \mathrm{L}^{-1}\right)$, Weq is the equivalent weight and $\mathrm{Pd}$ is the purity degree of $97 \%$. ECW was measured using a portable digital conductivity meter (microprocessor, model CD-860, Instrutherm ${ }^{\circ}$ ).

Irrigation was performed daily, and saline water was applied from 10 days after sowing. Water volume applied was determined by the drainage lysimetry method, by the difference between the amount of water applied and drained, which thus keeping the soil at field capacity.

Table 1. Treatments generated through the centre composite design (CCD) matrix.

\begin{tabular}{|c|c|c|c|c|}
\hline \multirow[b]{2}{*}{ Treatments } & \multicolumn{2}{|c|}{ Levels } & \multicolumn{2}{|c|}{ Dose } \\
\hline & $\begin{array}{c}\text { ECw } \\
\left(\mathrm{dS} \mathrm{m}^{-1}\right)\end{array}$ & $\begin{array}{c}\text { BD } \\
\left(\mathrm{mL} \mathrm{L}^{-1}\right)\end{array}$ & $\begin{array}{c}\text { ECw } \\
\left(\mathrm{dS} \mathrm{m}^{-1}\right)\end{array}$ & $\begin{array}{c}\text { BD } \\
\left(\mathrm{mL} \mathrm{L}^{-1}\right)\end{array}$ \\
\hline T1 & -1 & -1 & 1.23 & 1.45 \\
\hline $\mathrm{T} 2$ & -1 & 1 & 1.23 & 8.55 \\
\hline T3 & 1 & -1 & 4.77 & 1.45 \\
\hline T4 & 1 & 1 & 4.77 & 8.55 \\
\hline T5 & $-\alpha$ & 0 & 0.50 & 5.00 \\
\hline T6 & $\alpha$ & 0 & 5.50 & 5.00 \\
\hline T7 & 0 & $-\alpha$ & 3.00 & 10.00 \\
\hline T8 & 0 & $\alpha$ & 3.00 & 0.00 \\
\hline T9 & 0 & 0 & 3.00 & 5.00 \\
\hline
\end{tabular}

$\mathrm{ECW}=$ electrical conductivity of irrigation water; $\mathrm{DB}=$ biostimulant doses. 
The biostimulant doses based on $A$. nodosum seaweed extracts (Acadian', Agritech, Canada) were applied 20 days after start irrigation with saline water. The extracts had the following characteristics: $8.12,6.82,12.00,1.60,2.03$, and $8.16 \mathrm{~g} \mathrm{~kg}^{-1} \mathrm{~N}, \mathrm{P}, \mathrm{K}, \mathrm{Ca}, \mathrm{Mg}$, and $\mathrm{S}$, respectively; 5.74, 13.60, $11.5,0.04,24.40$, and $20.000 \mathrm{mg} \mathrm{kg}^{-1} \mathrm{~B}, \mathrm{Cu}, \mathrm{Fe}, \mathrm{Mn}, \mathrm{Zn}$, and $\mathrm{Na}$ respectively; potassium hydroxide, with $61.48 \mathrm{~g} \mathrm{~L}^{-1}$ watersoluble $\mathrm{K}_{2} \mathrm{O} ; 69.60 \mathrm{~g} \mathrm{~L}^{-1}$ total organic carbon; and $1.16 \mathrm{~g} \mathrm{dm}^{-3}$ density (Silva et al., 2016). Doses were divided into six foliar applications, performed weekly in the late afternoon by spraying $100 \mathrm{~mL}$ solution per plant.

At 75 days after saline application, plant biomass was evaluated. Plants were removed from the pots, separated into leaves, stem, and roots, then stored in paper bags and dried in a forced circulation oven $\left(65^{\circ} \mathrm{C} ; 72\right.$ hours) to determine the dry phytomass of each plant organ on a precision analytical scale. Also, shoot (leaves plus stem) and total (leaves plus stem plus roots) phytomass were obtained by the sum of dry phytomass of plant organs, and results were expressed as $\mathrm{g}$ per plant.

For plant appraisal, plant height and stem diameter were measured, and values were used to calculate the Dickson Quality Index (DQI) by the Equation 2 (Dickson et al., 1960).

$$
\mathrm{DQI}=\frac{\mathrm{TDP}}{\frac{\mathrm{PH}}{\mathrm{SD}}+\frac{\mathrm{SDP}}{\mathrm{RDP}}}
$$

where TDP is the total dry phytomass, $\mathrm{PH}$ is the plant height, SD is the stem diameter, SDP is the shoot dry phytomass, and RDP is the root dry phytomass.

Also, chlorophyll (Chl) fluorescence was analyzed by using a portable modulated fluorometer (Model OS-30p, Sciences Inc., Hudson, USA). Leaf clamps were placed for 30 minutes for leaf adaptation to darkness, then minimum fluorescence $\left(F_{0}\right)$ and maximum fluorescence $\left(F_{m}\right)$ variables were calculated. Also, variable fluorescence $\left(F_{v}=F_{m}-F_{0}\right)$, effective quantum yield of energy conversion $\left(F_{v} / F_{0}\right)$, and maximum quantum yield of PSII $\left(F_{v} / F_{m}\right)$ were calculated. In turn, pigment concentration ( $\mathrm{Chl} \mathrm{a,} \mathrm{Chl} \mathrm{b,} \mathrm{Chl} \mathrm{a}+\mathrm{b}$, and $\mathrm{Chl} \mathrm{a} / \mathrm{b}$ ) was determined by using a portable chlorophyll meter (ClorofiLOG ${ }^{\circ}$, CFL 1030 model, Falker, Porto Alegre, RS), with values expressed as Falker chlorophyll index (FCl).

The data were submitted to analysis of variance by the $F$ test $(p<0.05)$, the results being significant for the interaction between the factors presented by means of the response surface and those isolated by means of quadratic or linear polynomial regression, being used the $R$ software ( $R$ Core Team 2020).

\section{Results}

There was a significant interaction between the $\mathrm{ECW}$ and $\mathrm{BD}$ for root, leaf and total phytomass, $\mathrm{DQI}, \mathrm{F}_{\mathrm{v}} / \mathrm{F}_{0}$ and $\mathrm{Chl} \mathrm{a} / \mathrm{b}$ $(p<0.05$; Figure 1$)$.

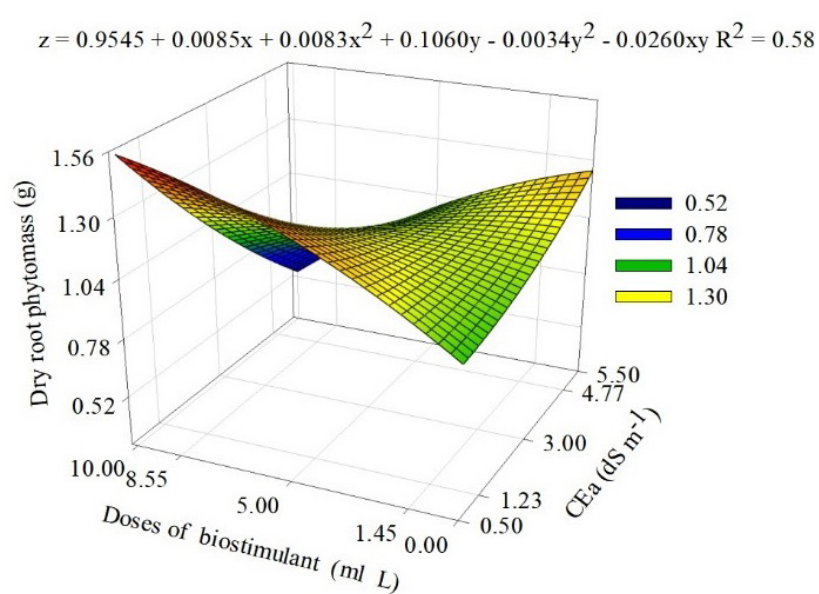

B. $z=0.8255+0.0374 x-0.00056 x^{2}+0.0309 y+0.000097 y^{2}-0.0147 x y R^{2}=0.53$

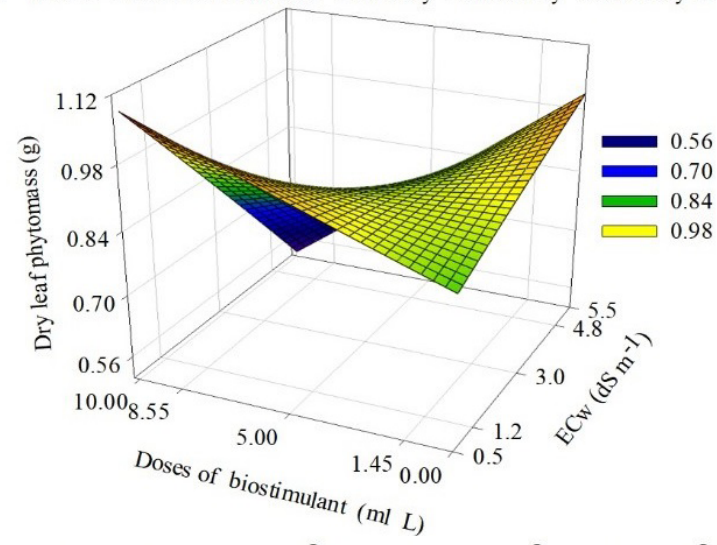

C. $z=2.264-0.156 \mathrm{x}+0.0268 \mathrm{x}^{2}+0.127 \mathrm{y}-0.0038 \mathrm{y}^{2}-0.0341 \mathrm{xy} \mathrm{R}^{2}=0.74$

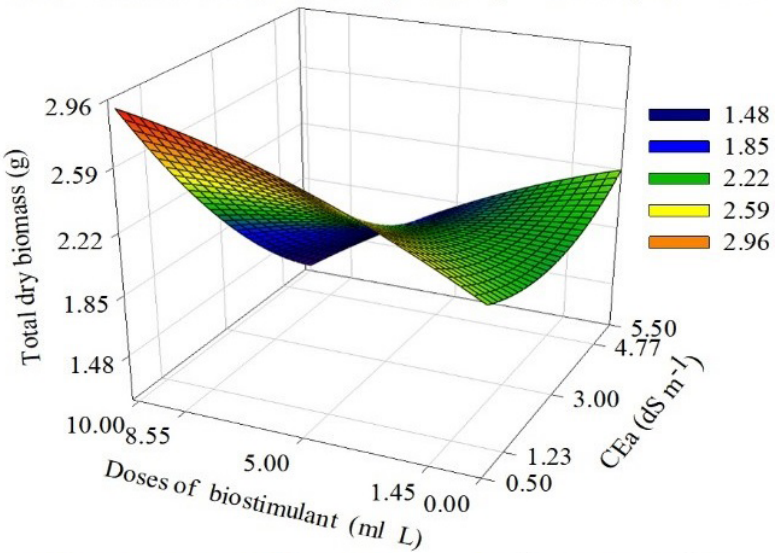

D. $z=0.340+0.0041 \times 0.0027 \mathrm{x}^{2}+0.0381 \mathrm{y}-0.0023 \mathrm{y}^{2}-0.0058 \mathrm{xy} \mathrm{R}^{2}=0.68$

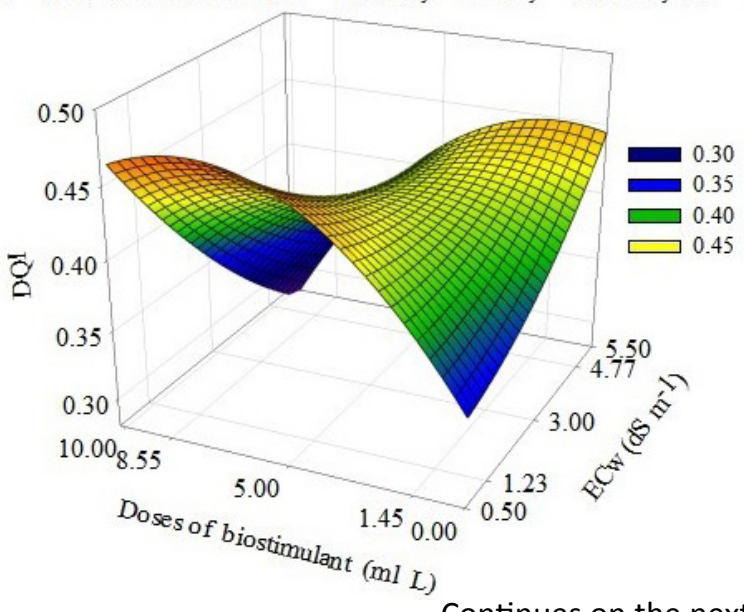

Continues on the next page 
Continuation of Figure 1

E. $z=3.745+0.134 x-0.027 x^{2}+0.088 y-0.013 y^{2}+0.017 x y R^{2}=0.79$

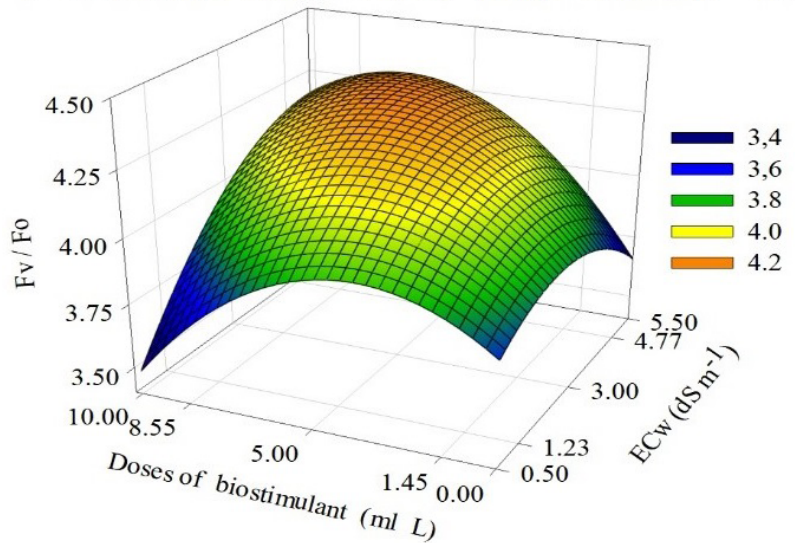

F. $z=5.073-0.170 x-0.012 x^{2}-0.108 y-0.0028 y^{2}+0.037 x y \quad R^{2}=0.60$

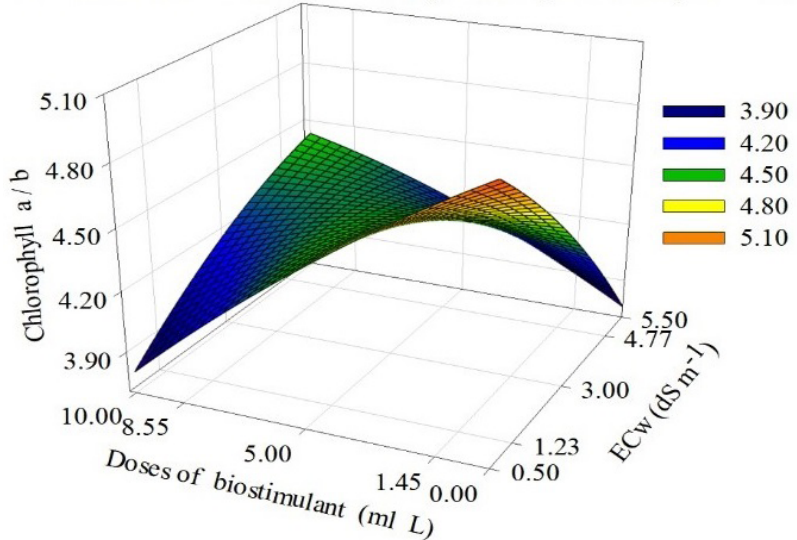

Figure 1. Dry root mass $(A)$, leaves $(B)$ total $(C)$, Dickson quality index - DQI (D), $F_{v} / F_{0}(E)$ ratio and chlorophyll a/b $(F)$ ratio Physalis peruviana L., submitted to electrical conductivity of irrigated water and doses of Ascophyllum nodosum based biostimulant.

Plants showed maximum root (1.54 g, Figure $1 \mathrm{~A})$ and leaf $(1.08 \mathrm{~g}$, Figure $1 \mathrm{~B})$ phytomass when they were irrigated with water of estimated $0.52 \mathrm{dS} \mathrm{m}^{-1}$ and treated with 9.9 $\mathrm{mL} \mathrm{L}^{-1}$ biostimulant. But maximum total phytomass was observed with an application of $9.7 \mathrm{~mL} \mathrm{~L}^{-1}$ biostimulant (Figure 1C). In this sense, maximum DQI (0.48) was reached in plants irrigated with water of $0.50 \mathrm{dS} \mathrm{m}^{-1}$, but when a lower biostimulant dose was applied (7.63 $\mathrm{mL} \mathrm{L}^{-1}$ ) (Figure 1D). Above these concentrations, DQI declined.

In contrast, $F_{v} / F_{0}$ increased (up to 4.32 ) with increasing salinity of irrigation water (up to $4.38 \mathrm{dS} \mathrm{m}^{-1}$ ) and an application of $6.3 \mathrm{~mL} \mathrm{~L}^{-1}$ biostimulant (Figure $1 \mathrm{E}$ ). Whereas $\mathrm{Chl}$ a/b strongly decreased due to salinity, but it was stimulated by seaweed extract application (Figure 1F). Moreover, regardless of biostimulant use, increased ECW negatively affected shoot dry phytomass accumulation as well as it reduced $F_{0}, F_{v}, F_{m}$ and $\mathrm{F}_{\mathrm{v}} / \mathrm{F}_{\mathrm{m}} \mathrm{Chl}$ fluorescence variables (Figure 2). Plants accumulated $26.7 \%$ less phytomass when plants were irrigated with water of $5.5 \mathrm{dS} \mathrm{m}^{-1}$ compared with $0.5 \mathrm{dS} \mathrm{m}^{-1}$ (Figure 2A). Similarly, $F_{0}, F_{v^{\prime}}$ and $F_{m}$ were 4.3 (Figure 2B), 8.2 (Figure $2 \mathrm{C}$ ) and $7.7 \%$ (Figure 2D) lower in plants irrigated with water of $5.5 \mathrm{dS} \mathrm{m}^{-1}$. Thereby, Fv/Fm ranged from 0.76 to 0.86 electrons quantum ${ }^{-1}$ depending on ECW used (Figure 2E).
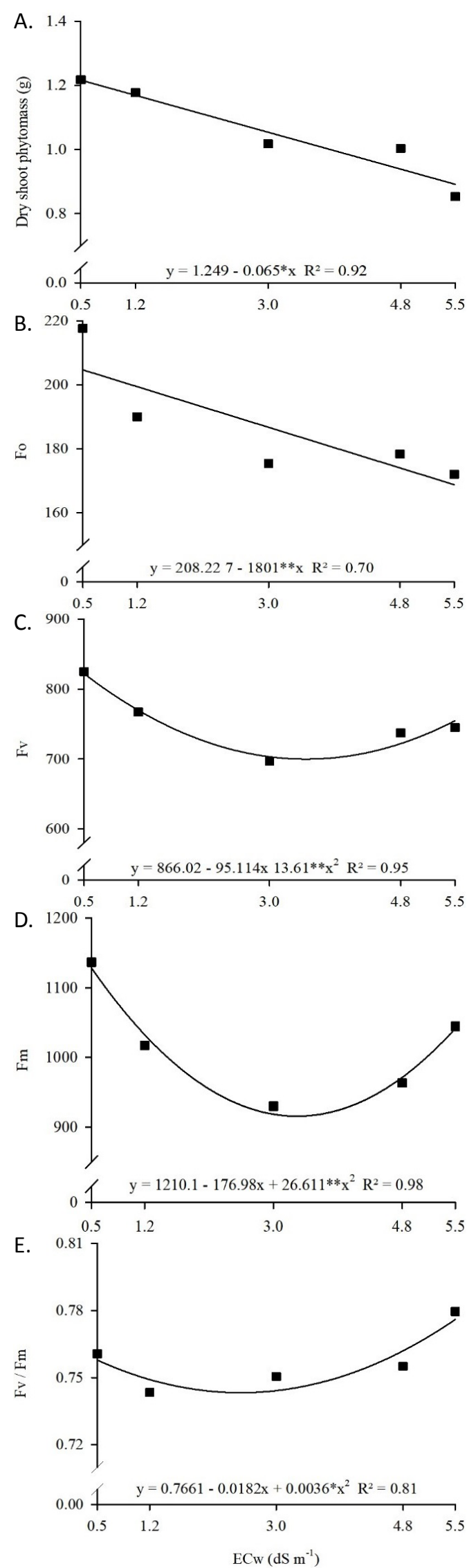

Figure 2. Dry shoot weight $(A)$, initial fluorescence $-F_{0}(B)$, variable fluorescence $-F_{v}(C)$, maximum fluorescence $-F_{m}(D)$ and FSII quantum yield $-F_{v} / F_{m}$ (E) from Physalis peruviana L., plants submitted to electrical conductivity of irrigation water. 
On the other hand, biostimulant increased by $40 \%$ the phytomass accumulation in stem in plants treated with $10 \mathrm{~mL}$ $\mathrm{L}^{-1}$ compared to non-treated plants $\left(0.0 \mathrm{~mL} \mathrm{~L}^{-1}\right)$ (Figure $\left.3 \mathrm{~A}\right)$. However, phytomass accumulation in shoot decreased by $20.2 \%$ (Figure 3B). Differently, $F_{0}, F_{v}$ and Fm increased by 8.2 (Figure 3C), 10.7 (Figure 3D) and $13.4 \%$ (Figure $3 \mathrm{E}$ ) respectively in plants treated with $3.6,4.0$ and $4.1 . \mathrm{mL} \mathrm{L}^{-1}$ biostimulant.

\section{Discussion}

The application of the doses of the biostimulant of seaweed extracts from $A$. nodosum mitigated the deleterious effects of salt stress, with a beneficial effect on the biomass of the root, leaf and total of $P$. peruviana plants. The beneficial effect on biomass yield and accumulation has been previously reported by Yildiztekin et al. (2018) in pepper plants (Capsicum annuum L.). Attenuating effect of biostimulant is associated with growthpromoting substances contained in this seaweed extract. Such compounds affect the physiological state of cells and, consequently, of plant tissues, causing positive and different responses in all plant growth stages (Neumann et al., 2017).

Other authors also observed higher phytomass accumulation in plants after they were treated with seaweed extracts. As reported by Silva et al. (2016), pond apple (Annona glabra L.) plants also treated with $A$. nodosum extract accumulated 85.0 and $87.39 \%$ more phytomass in shoot and root, respectively, than non-treated plants. Other seaweed extracts also increased plant biomass. Rouphael et al. (2017) found that application of $3 \mathrm{~mL} \mathrm{~L}^{-1}$ Ecklonia maximus extract increased by $17.4 \%$ the plant shoot biomass in zucchini (Cucurbita pepo L.) plants under salinity conditions. Moreover, results showed that biostimulant application attenuated salt stress damage on the photosynthetic apparatus since ECW above $4.38 \mathrm{dS} \mathrm{m}^{-1}$ reduced $F_{v} / F_{0}$ and hence the plant photochemical energy conversion. Thus, osmoprotectants contained in the $A$. nodosum extracts exerted photoprotective action on energy dissipation and excitation as well as on electron transport in plants under stress conditions (Demming-Adams et al., 2017).

The seaweed extract also contain amino acids and phytohormones, substances capable of mitigating damages caused by saline and oxidative stress in plants by increasing cell membrane as well as antioxidant and enzyme activity. Because of this, application of these extracts improved plant performance under saline stress conditions and favouring the plant vegetative growth (Raghunandan et al., 2019).

The Chl a / b ratio suffered a positive effect of the biostimulant in $\mathrm{P}$. peruviana plants, where under stress conditions, the plants reduced $\mathrm{Chl}$ a / b, indicating that the application of $A$. nodosum extract increased the content of Chl a and biogenesis chloroplasts, delaying the degradation of chlorophyll, as previously reported by Jannin et al. (2013) in rapeseed plants (Brassica napus L.) in agricultural environments managed with salt. A decrease in photosynthetic pigment concentration may result in changes in excitation energy efficiency by light-harvesting complexes and damages in the photosynthetic reaction centre, as well as it affects the
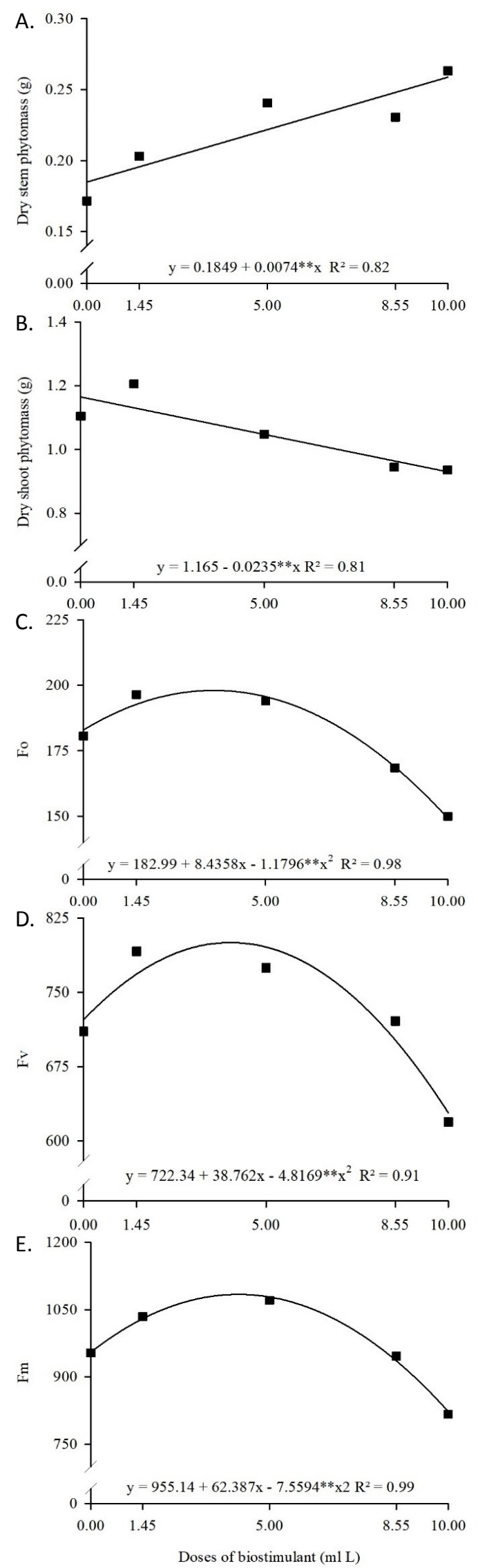

Figure 3. Phytomass dry stem (A), dry shoot (B), initial fluorescence $-F_{0}(C)$, variable fluorescence $-F_{v}(D)$ and maximum fluorescence $-F_{m}(E)$ from Physalis peruviana $L$. plants submitted at doses of Ascophyllum nodosum based biostimulant. 
splitting of water and hence limits electron transferring for photochemical process continuity (Tatagiba et al., 2014; Melo et al., 2017). However, similar responses of plants for chlorophyll content and fluorescence in our results demonstrates that the photosynthetic apparatus was little affected by salinity when plants were treated with the seaweed extract.

The deleterious effect of salinity on the photosynthetic apparatus is common in Solanaceae plants. For instance, in bell pepper ( $C$. annuum L.) plants, $F_{0}, F_{v}$ and $F_{m}$ reduced significantly above the estimated ECW level of $3.98 \mathrm{dS} \mathrm{m}^{-1}$ (Cavalcante et al., 2019). Such response was also observed in tomato (S. Iycopersicum L.) plants under increased salinity of irrigation water (Tatagiba et al., 2014). Similarly, Silva et al. (2015) found that $F_{v}$ and $F_{m}$ reduced in eggplant (S. melongena L.) plants under water restriction.

Our results suggest biostimulant application may increase biomass accumulation and reduce $\mathrm{Chl}$ fluorescence in $P$. peruviana plants by providing and balancing growth regulators in the plant, which favour cell division and improve stem biomass production concerning shoot. Phytohormones, such as cytokine, jasmonate, salicylic acid and ethylene, as well as betaine, polyamines and mineral nutrients contained in the biostimulant may act in plant growth regulation and therefore favouring biomass accumulation (Jannin et al., 2013; Ye \& Murata, 2016; Kałużewicz et al., 2017). At the concentrations used in this study, biostimulant preserved the photosynthetic apparatus thereby keeping light transfer to reaction centres which thus resulted in higher energy conversion and photosystem activity. Also, it increased Chl content by providing nitrogen to plant cells thereby improving photosynthetic activity and hence photoassimilates production (Sosnowski et al., 2019).

\section{Conclusions}

The salinity of irrigation water reduces the phytomass production and the fluorescence and chlorophyll indices of Physális peruviana plants.

The $9.9 \mathrm{~mL} \mathrm{~L}^{-1}$ dose of $A$. nodosum extract-based biostimulant attenuates the effect of salt stress on $P$. peruviana biomass production.

Biostimulant application up to $4.1 \mathrm{~mL} \mathrm{~L}^{-1}$ increases chlorophyll fluorescence rates in P. peruviana plants.

\section{Acknowledgements}

The Coordination for the Improvement of Higher Education Personnel (CAPES) and the National Council for Scientific and Technological Development (CNPq) for the granting of scholarships to graduate students of the work.

\section{Compliance with Ethical Standards}

Author contributions: Conceptualization: JSN, RTF; Data curation: JTAF, FRAF, WCF; Formal analysis: JSN, RTF; FRAF;
WCF; Investigation: JTAF, FJSP, MFM; Methodology: JSN, TJD, RTF; Project administration: JSN, RTF; Resources: JSN, FJSP, TJD; Supervision: TJD; Validat; Writing - original draft: JSN, MFM, TJD; Writing - review \& editing: JSN, TJD.

Conflict of interest: The authors declare no conflict of interest.

Funding: This work has no financial funding.

\section{Literature Cited}

Abdel-Raouf, N.; Al-Homaidan, A. A.; Ibraheem, I. B. M. Microalgae and wastewater treatment. Saudi Journal of Biological Sciences, v.19, n.3, p.257-275, 2012. https://doi.org/10.1016/j. sjbs.2012.04.005.

Al-Maliki, S.; Adnam, A.; Al-Mammory, K. A. A. H.; Al-Moslimawi, A. A. Effect of Ascophyllum extract and water stress on soil biological properties and growth of onion (Allium cepa L.). Indiam Journal of Ecology, v.46, n.4, p.796-803, 2019. http:// indianecologicalsociety.com/society/wp-admin/pdf/Final\%20 46(4)\%201_removed\%20(1)-20.pdf. 06 Sep. 2020.

Almeida, J. P. M.; Mendonça, V.; Alves, A. A.; Cardoso Neto, R.; Costa, L. P.; Silva, F. S. O. Morphometric responses and tolerance of pomegranate seedlings irrigated with saline water. Revista Brasileira de Engenharia Agrícola e Ambiental, v.23, n.5, p.341346, 2019. https://doi.org/10.1590/1807-1929/agriambi. v23n5p341-346.

Cavalcante, A. R.; Santos Júnior, J. A.; Furtado, G. F.; Chaves, L. H. G. Gas exchanges and photochemical efficiency of hydroponic bell pepper under salinity and plant density. Revista Brasileira de Engenharia Agrícola e Ambiental, v.23, n.1, p.3-8, 2019. https:// doi.org/10.1590/1807-1929/agriambi.v23n1p3-8.

Demming-Adams, B.; Burch, T. A.; Stewart, J. J.; Savage, E. L.; Adams, W. W. Algal glycerol accumulation and release as a sink for photosynthetic electron transport. Algal Research, v.21, p.161168, 2017. https://doi.org/10.1016/j.algal.2016.11.017.

Dickson, A.; Leaf, A. L.; Hosner, J. F. Quality appraisal of white spruce and white pine seedling stock in nurseries. Forestry Chronicle, v.36, n.1, p.10-13, 1960. https://doi.org/10.5558/tfc36010-1.

Empresa Brasileira de Pesquisa Agropecuária - Embrapa. Sistema brasileiro de classificação de solos. 5.ed. Brasília: Embrapa, 2018. $353 \mathrm{p}$.

Fischer, G.; Almanza-Merchán, P. J.; Miranda, D. Importancia y cultivo de la uchuva (Physalis peruviana L.). Revista Brasileira de Fruticultura, v.36, n.1, p.1-15, 2014. https://doi. org/10.1590/0100-2945-441/13.

Hang, Y.; Qu, M.; Ukkusuri, S. Optimizing the design of a solar cooling system using central composite design techniques. Energy and Buildings, v.43, n.4, p.988-994, 2011. https://doi.org/10.1016/j. enbuild.2010.12.024.

Jannin, L.; Arkoun, M.; Etienne, F.; Lainé, P.; Goux, D.; Garnica, M.; Fuentes, M.; Francisco, S. S.; Baigorri, R.; Cruz, F.; Houdusse, F.; Garcia-Mina, J. M.; Yvin, J. C.; Ourry, A. Brassica napus growth is promoted by Ascophyllum nodosum (L.) Le Jol. Seaweed extract: microarray analysis and physiological characterization of $N, C$ and S metabolisms. Journal of Plant Growth Regulation, v.32, n.1, p.31-52, 2013. https://doi.org/10.1007/s00344-012-9273-9. 
Jithesh, M. N.; Pushp, S.; Shukla, P.; Kant, J. J.; Critchley, A. T.; Prithivira, B. Physiological and transcriptomics analyses reveal that Ascophyllum nodosum extracts induce salinity tolerance in Arabidopsis by regulating the expression of stress responsive genes. Journal of Plant Growth Regulation, v.38, n.2, p.463-478, 2019. https://doi.org/10.1007/s00344-018-9861-4.

Kałużewicz, A.; Krzesiński, W.; Spiżewski, T.; Zaworska, A. Effect of biostimulants on several physiological characteristics and chlorophyll content in broccoli under drought stress and re -watering. Notulae Botanicae Horti Agrobotanici ClujNapoca, v.45, n.1, p.197-202, 2017. https://doi.org/10.15835/ nbha45110529.

Lima, K. L.; Cavalcante, L. F.; Feitosa Filho, J. C. Efeito de fontes e níveis de salinidade da água de irrigação sobre a germinação e o crescimento da pinheira. Engenharia Agrícola, v.21, n.2, p.135144, 2001.

Melo, H. F.; Souza, E. R.; Duarte, H. H. F.; Cunha, J. C.; Santos, H. R. B. Gas exchange and photosynthetic pigments in bell pepper irrigated with saline water. Revista Brasileira de Engenharia Agrícola e Ambiental, n.1, v.21, p.38-43, 2017. https://doi. org/10.1590/1807-1929/agriambi.v21n1p38-43.

Michalak, I.; Górka, B.; Wieczorek, P. P.; Rój, E.; Lipok, J.; Łęska, B.; Messyasz, B.; Wilk, R.; Schroeder, G.; Dobrzyńska-Inger, A.; Chojnacka, K. Supercritical fluid extraction of algae enhances levels of biologically active compounds promoting plant growth. European Journal of Pychology, v.51, n.3, p.243-252, 2016. https://doi.org/10.1080/09670262.2015.1134813.

Neumann, E. R.; Resende, J. T. V.; Camargo, L. K. P.; Chagas, R. R.; Lima Filho, R. B. Produção de mudas de batata doce em ambiente protegido com aplicação de extrato de Ascophyllum nodosum. Horticultura Brasileira, v.35, n.4, p.490-498, 2017. https://doi. org/10.1590/S0102-053620170404.

Popescu, M. The role of seaweeds extracts as alleviators of salt stress in cucumber and tomato plants. Current Trends in Natural Sciences, v.9, n.17, p.201-204, 2020. https://doi.org/10.47068/ ctns.2020.v9i17.024.

R Core Team. R: A language and environment for statistical computing. Vienna: R Foundation for Statistical Computing, 2020.

Raghunandan, B. L.; Vyas, R. V.; Patel, H. K.; Jhala, Y. K. Perspectives of seaweed as organic fertilizer in agriculture. In: Panpatte, D.; Jhala Y. (Eds.). Soil fertility management for sustainable development. Singapore: Springer, 2019. Chap. 13, p 267-289. https://doi.org/10.1007/978-981-13-5904-0_13.
Rosa, V. R.; Santos, A. L. F.; Silva, A. A.; Peduti, M.; Sab, V.; Germino, G. H.; Cardoso, F. B.; Silva, M. A. Increased soybean tolerance to water deficiency through biostimulant based on fulvic acids and Ascophyllum nodosum (L.) seaweed extract. Plant Physiology and Biochemistry, v.158, n.1, p.228-243, 2021. https://doi. org/10.1016/j.plaphy.2020.11.008.

Rouphael, Y.; De Micco, V.; Carmen, A.; Raimondi, G.; Colla, G.; De Pascale, S. Effect of Ecklonia maxima seaweed extract on yield, mineral composition, gas exchange, and leaf anatomy of zucchini squash grown under saline conditions. Journal of Applied Phycology, v.29, n.1, p.459-470, 2017. https://doi.org/10.1007/ s10811-016-0937-x.

Silva, C. C.; Arrais, I. G.; Almeida, J. P. N.; Dantas, L. L. G. R.; Silva, F. S. O.; Mendonça, V. Extrato da alga Ascophyllum nodosum (L. Le Jolis na produção de porta-enxertos de Anonna glabra L. Revista de Ciências Agrárias, v.39, n.2, p.234-241, 2016. https://doi. org/10.19084/RCA15057.

Silva, F. G.; Dutra, W. F.; Dutra, A. F.; Oliveira, I. M.; Filgueiras, L. M. B.; Melo, A. S. Trocas gasosas e fluorescência da clorofila em plantas de berinjela sob lâminas de irrigação. Revista Brasileira de Engenharia Agrícola e Ambiental, v.19, n.10, p.946-952, 2015. https://doi.org/10.1590/1807-1929/agriambi.v19n10p946-952.

Soares, J.; Loterio, R. K.; Rosa, R. M.; Santos, M. O.; Nascimento, A. G.; Santos, N. T.; Willians, T. C. R.; Nunes-Nesi, A.; Martins, M. A. Scenedesmus sp. cultivation using commercial-grade ammonium sources. Annals of Microbiology, v.68, n.1, p.35-45, 2018. https:// doi.org/10.1007/s13213-017-1315-x.

Sosnowski, J.; Jankowski, K.; Truba, M.; Malinowska, E. Effect of Ecklonia maxima extract on photosynthesis activity and chlorophyll content of Medicago $\times$ varia Martyn leaves. Chilean Journal of Agricultural Research, v.79, n.2, p.257-265, 2019. https://doi.org/10.4067/S0718-58392019000200257.

Tatagiba, S. D.; Moraes, G. A. B. K. Nascimento, K. J. T. Peloso, A. F. Limitações fotossintéticas em folhas de plantas de tomateiro submetidas a crescentes concentrações salinas. Engenharia na Agricultura, v.22, n.2, p.138-149, 2014. https://doi. org/10.13083/1414-3984.v22n02a05.

Ye, W.; Murata, Y. Microbe associated molecular pattern signaling in guard cells. Frontiers in Plant Science, v.7, e00583, 2016. https:// doi.org/10.3389/fpls.2016.00583.

Yildiztekin, M.; Atum, A. L.; Kaya, C. Physiological effects of the brown seaweed (Ascophyllum nodosum) and humic substances on plant growth, enzyme activities of certain pepper plants grown under salt stress. Acta Biologica Hungarica, v.69, n.3, p.325-335, 2018. https://doi.org/10.1556/018.68.2018.3.8. 